\title{
Respon Terhadap Konflik Oleh Masyarakat Komunitas Kontu Dalam Kawasan Hutan Lindung Jompi Kabupaten Muna Sulawesi Tenggara
}

\author{
Laode Muhammad Iqbal ${ }^{1^{\star}}$, Muhammad Dassir ${ }^{1}$, Risma Illa Maulany ${ }^{1}$ \\ ${ }^{1}$ Fakultas Kehutanan Universitas Hasanuddin, Makassar \\ Email: laodemuh.iabal@gmail.com
}

\begin{abstract}
The case of conflict occurring in the Jompi protected forest is a conflict between the Kontu community and the Muna District Forest Service. The problems that occur because the community is not allowed to enter the protected forest area while the people from the past have lived and has dependent in the forest. The community's productive land is within Jompi's protected forest area. History notes that the protected forest area of Jompi has been traditionally utilized by the community of Kontu communities. So that social pressure of the community then manages the land in the Forest area without permission from the Forest Service. This is done by Kontu and the poor from the city of Raha to make ends meet. Based on this case, this study examines how the responses about the conflicts by Kontu communities in utilizing the Jompi protected forest area, Muna Regency, Southeast Sulawesi. Data analysis is done descriptively narrative which presents data descriptively in the form of chart, matrix to facilitate comprehension of data analysis result which have obtained more integrated. The results obtained in this study that the causes of the conflict that occurred between Kontu Community and Muna District Forest Service began in 1999, when the issuance of Forestry Ministerial Decree No. 454 / Kpts-II / 1999 by the Ministry of Forestry which designates the forest area of Southeast Sulawesi. Communities respond to conflict in different ways. Some communities respond strongly that those expressed in the form of resistance as their resistance to conflict and there is also a weak response, expressed by migration although not so much.
\end{abstract}

Key Words: Land, Protected Forest, Conflict, Kontu Communities.

DOI : http://dx.doi.org/10.24259/ihm.v11i1.4774

\section{PENDAHULUAN}

Pemanfaatan hutan oleh masyarakat sekitar disekitar hutan telah terjadi secara terus menerus dan dalam pengelolaanya mendapat tantangan yang cukup berat untuk mengelola hutan secara lestari dan berkelanjutan. Banyaknya pihak yang berkepentingan terhadap hutan menjadi alasan dari masing-masing pihak berbeda kebutuhan dan tujuannya. Kondisi inilah yang menimbulkan konflik antara masyarakat dengan institusi negara. Konflik adalah suatu proses sosial yang berlangsung dengan melibatkan orangorang atau kelompok-kelompok yang saling menantang dengan ancaman kekerasan. Penelitian Dassir (2014) menjelaskan bahwa dalam bentuknya yang ekstrem, konflik itu dilangsungkan tidak hanya sekadar untuk mempertahankan hidup dan eksistensi (jadi bersifat defensive), akan tetapi juga bertujuan sampai ke taraf pembinasaan eksistensi orang atau kelompok lain yang dipandang sebagai lawan atau sainganya.

Konflik menjadi hal yang tidak terhindarkan dalam pengelolaan hutan di Indonesia. Konflik mulai mencuat ketika Indonesia dilanda krisis moneter dan terjadi reformasi pada tahun 1998, kehidupan ekonomi masyarakat semakin memburuk sehingga masyarakat mengandalkan sumberdaya hutan karena hanya itu saja komoditas yang dapat digunakan untuk memenuhi kebutuhan hidup sehari-harinya. Wulan et al (2004) menulis, setelah era Orde Baru peningkatan jumlah dan frekuensi konflik makin besar terjadi dan cenderung disertai kekerasan. Kecenderungan ini antara lain disebabkan karena dampak reformasi terhadap perilaku masyarakat local. Reformasi telah membuat masyarakat sadar kan haknya dan 
akhirnya berani menuntut untuk mendapatkan porsi manfaat yang wajar dari keberadaan hutan diwilayah mereka. Akibat tuntutan mereka kurang ditanggapi dengan baik dan ketidakpastian dalam penegakan hukum, keberanian masyarakat lokal akhirnya diekspresika dalam bentuk perlawanan terbuka terhadap pengelola hutan.

Konflik yang terjadi dalam pengelolaan hutan umumnya berkaitan dengan penguasaan lahan, kondisi ini yang terjadi pada masyarakat Kontu yang bermukim pada kawasan hutan lindung Jompi. Permasalahan konflik yang terjadi pada kawasan hutan lindung Jompi diawali dengan beberapa kebijakan yang muncul dan kemudian menyebabkan kontroversi bagi masyarakat di sekitar hutan lindung Jompi. Kasus konflik yang terjadi di hutan lindung Jompi adalah konflik antara masyarakat Kontu dengan Pemerintah Daerah dalam hal ini Dinas Kehutanan Kabupaten Muna, karena masyarakat tidak diperbolehkan masuk ke kawasan hutan lindung sedangkan masyarakat dari dulu sudah bergantung hidup pada hutan. Masyarakat lalu memaksa masuk ke kawasan hutan dan mengambil sumberdaya hutan tanpa izin dari Dinas Kehutanan. Sumberdaya hutan yang ada pada kawasan hutan lindung Jompi adalah kayu. Selain itu masyarakat juga memaksa untuk menanam tanaman jangka pendek pada kawasan hutan tersebut tersebut.

Menurut Larson (2013) penguasaan lahan hutan menentukan siapa yang diizinkan untuk menggunakan sumber daya apa, dengan cara bagaimana, selama berapa lama dan dengan syarat apa dan siapa yang berhak mengalihkan kepada pihak lain bagaimana caranya. Berdasarkan hasil observasi dan wawancara dengan beberapa responden diketahui bahwa respon masyarakat terkait konflik ini didefinisikan sebagai suatu sikap masyarakat dalam menanggapi konflik sumberdaya hutan yang terjadi antara pihak pemerintah dan masyarakat. Oleh sebab itu dalam upaya melihat sejauh mana konflik yang terjadi dikawasan hutan lindung Jompi perlu dilakukan penelitian untuk menggali informasi terkait respon masyarakat terhadap konflik.

Tujuan dari penelitian ini adalah untuk melihat sikap positif masyarakat digambarkan respon yang kuat yaitu konflik yang terjadi harus dilawan dan sikap negatif masyarakat digambarkan dengan respon yang lemah yaitu masyarakat masih ada alternatif lain yang bisa dilakukan untuk memenuhi kebutuhan tanpa perlawanan. Selain itu hasil dari penelitian ini diharapkan dapat dijadikan sebagai sumber informasi dalam kajian_kajian terkait konflik pengelolaan hutan.

\section{METODE PENELITIAN}

\subsection{Waktu dan Tempat Penelitian}

Penelitian ini dilaksanakan di kawasan Hutan Lindung Jompi pada Komunitas Kontu Kabupaten Muna Provinsi Sulawesi Tenggara. Pengumpulan data lapangan, pengolahan dan analisis data berlangsung dari awal bulan Agustus sampai akhir bulan Oktober 2017. 


\subsection{Populasi dan Sampel}

Populasi pada penelitian ini adalah beberapa komponen masyarakat sekitar Kawasan Hutan Lindung Jompi, tokoh masyarakat, apparat pemerintah setempat, LSM, dan Dinas Kehutanan. Jumlah responden untuk masing-masing komponen akan ditentukan kemudian, namun penentuan lokasi pengambilan data responden ditentukan berdasarkan keberadaan konflik pada daerah tersebut denga Pemerintah Daerah Kabupaten Muna

\subsection{Tahapan Pelaksanaan}

\subsubsection{Studi Literatur}

Studi Literatur dipakai untuk memperoleh data melalui bahan-bahan tertulis berupa dokumen peraturan, laporan pelaksanaan arsip lain yang relevan dengan penelitian. Studi dokumentasi dimaksudkan untuk menghimpun sebanyak mungkin pengetahuan sesuai dengan permasalahan penelitian dan bertujuan untuk mengotipmalkan kerangka teori dalam menentukan arah konsep dan pembahasan penelitian serta menjelaskan kedudukan masalah dalam konteks yang sesuai. Dokumendokumen yang ada akan dianalisis dengan analisis isi teknik ini dilakukan untuk melengkapi informasi peneliti disamping untuk mendukung teknik-teknik pengumpulan data melalui wawancara dan observasi.

\subsubsection{Wawancara}

Adapun yang menjadi sumber data dalam penelitian ini adalah informan. Informan dipilih secara purposive, objek penelitian yang dianggap kompeten dan representative berdasarkan tujuan penelitian (key mendalam informan). Di dalam melakukan wawancara peneliti dilengkapi dengan instrument dalam bentuk pedoman wawancara yang disusun berdasarkan parameter yang dibutuhkan dan relevan sesuai dengan maksud dan tujuan penelitian namun tetap membuka peluang memperoleh informasi yang tidak terungkap melalui cara-cara lain. Wawancara akan dilakukan secara mendalam dari pertanyaanpertanyaan yang diajukan secara fleksibel, terbuka, dan tepat sasaran dengan penelitian ini. Pedoman wawancara terdiri dari beberapa pertanyaan utama yang dijadikan pedoman oleh peneliti. Pertanyaan tersebut dapat dikembangkan pada saat wawancara sehingga sangat dimungkinkan bagi peneliti untuk menggali jawab lebih mendalam kepada informan sampai peneliti merasa cukup untuk menjawab permasalahan penelitian.

\subsection{Analisis Data}

Dalam penelitian kualitatif, analisis data dilakukan sejak awal penelitian dan selama proses penelitian dilaksanakan. Data yang diperoleh digunakan untuk mengidentikasi konflik-konflik yang terjadi pada Kawasan Hutan Lindung Jompi. Kemudian data-data yang diperoleh dari hasil wawancara, analisis dokumen/literature direduksi melalui proses pemilihan, pengkategorian data-data berdasarkan 
kepentingan sub-bab yang dibahas, disesuaikan dan dijabarkan secara subjektif dengan sudut pandang informan dan responden.

Penyajian data dilakukan secara naratif deksriptif yang menyajikan data secara deskriptif dengan menggunakan bentuk bagan, table atau matriks untuk mempermudah pemahaman mengenai hasil analisis data yang telah diperoleh secara lebih terpadu. Terakhir, penarikan kesimpulan dengan melakukan verifikasi data yaitu melakukan pemikiran ulang dan peninjauan ulang data untuk menarik kesimpulan yang kokoh dan tepat.

\section{HASIL DAN PEMBAHASAN}

\subsection{Faktor Penyebab Konflik}

Konflik yang terjadi di Kawasan Hutan Lindung Jompi diidentifikasi juga berdasarkan hasil wawancara dan observasi dengan berbagai pihak. Sebagian besar konflik atas sumberdaya hutan mempunyai sebab-sebab ganda, biasanya kombinasi dari masalah-masalah dalam hubungan antara pihak yang mengarah pada konflik terbuka. Karena seringkali menjadi rumit, sangat penting untuk mendefinisikan masalah-masalah dalam hubungan antara pihak yang bertikai.

Penyebab konflik yang terjadi antara Komunitas Kontu dengan Dinas Kehutanan Kabupaten Muna berawal di tahun 1999, ketika dikeluarkannya SK Menhutbun No. 454/Kpts-II/1999 oleh Departemen Kehutanan yang menunjuk kawasan hutan Sulawesi Tenggara yang menurut terjemahan Pemkab. Muna, kawasan Kontu adalah kawasan hutan lindung yang harus dikosongkan oleh masyarakat. Masyarakat sendiri sampai saat ini tetap berada pada kawasan hutan lindung karena menganggap bahwa Kontu adalah warisan adat leluhur mereka. Perbedaan pandangan inilah yang membuat konflik sempat mencuat antara masyarakat dan Dinas Kehutanan Kabupaten Muna. Menurut masyarakat seperti yang diutarakan oleh salah satu responden (Wa Ndoria):

“Aturan itu jelas membuat keterbatasan terhadap jumlah lahan milik, sementara kebutuhan selalu meningkat baik fungsi maupun manfaat lahan tersebut bagi masyarakat”

Perbedaan pemahaman lebih disebabkan oleh kurangnya komunikasi antara pihak pemerintah dan masyarakat. Masyarakat beranggapan bahwa sebelum penetapan kawasan hutan lindung tidak ada sosialisasi awal, seperti yang dituturkan oleh salah satu responden (La Jumerda):

“Tahun 2002 tiba-tiba Polisi Pamong Praja datang merusak tanaman kami dengan mecabutinya dan membakarnya, termasuk pondokan yang ada dalam kebun. Pemerintah menganggap bahwa masyarakat melakukan tindakan penyerobotan lahan milik negara sehingga harus dihentikan tanpa melihat kondisi dan keinginan masyarakat". 
Menurut pemerintah tindakan yang dilakukan masyarakat adalah hal yang tidak benar secara aturan kehutanan. Sedikit banyak pemerintah tahu kalau masyarakat membutuhkan lahan guna membantu kebutuhan hidup mereka. Menurut UU RI No. 41 tahun 1999 pasal 26 ayat (1) dan (2) dan PP RI No. 34 tahun 2002 tentang Tata Hutan Dan Penyusunan Rencana Pengelolaan Hutan, Pemanfaatan Hutan Dan Penggunaan Kawasan Hutan pasal 18-21, pemanfaatan hutan lindung dapat berupa pemanfaatan kawasan, pemanfaatan jasa lingkungan dan pemungutan hasil hutan bukan kayu (HHNK). Pemanfaatan hutan lindung dilaksanakan melalui pemberian izin usaha pemanfaatan kawasan, izin usaha pemanfaatan jasa lingkungan dan izin pemungutan HHNK. Terdapat larangan melakukan kegiatan budidaya kecuali yang tidak mengganggu fungsi lindung berdasar Keppres RI No. 32 tahun 1990.Jika dilihat dari sisi masyarakat, konflik yang terjadi merupakan bentuk perlawanan dari masyarakat yang bermotif ekonomi. Perlawanan dengan motif ekonomi tampak pada pemenuhan kebutuhan masyarakat, dengan cara menanami lahannya dengan tanaman pertanian seperti jagung, pisang, ubi kayu dan sayuran, meski tidak diizinkan oleh Dinas Kehutanan Kabupaten Muna. Perlawanan juga bersumber dari kebutuhan akan ruang kelola (kebutuhan atas lahan pertanian) oleh masyarakat, hal ini disebabkan karena tingkat kepemilikan lahan masyarakat pada umumnya kecil.

Akibat dari perbedaan pandangan ini adalah terjadinya sengketa antara pihak Pemerintah yakni Dinas Kehutanan Kabupaten Muna dan pihak masyarakat Kontu yang berujung pada konflik fisik pada tahun 2003 dan 2005. Pihak Pemerintah memiliki beberapa acuan yang dijadikan sebagai landasan hukum yaitu:

a. Penetapan Belanda bersama Raja Muna dan Kepala Distrik Katobu Muna sesuai dengan yang tertuang dalam SK No.32 Reg.H.1.1933.

b. SK Menhutbun No. 454/Kpts-II/1999 tentang Penunjukan Kawasan Hutan dan Perairan Wilayah Propinsi Daerah Tingkat I Sulawesi Tenggara.

c. UU No. 41 Tahun 1999 tentang Kehutanan.

Pemerintah Kabupaten Muna menjadikan peraturan tersebut sebagai acuan bahwa Kontu merupakan bagian hutan lindung Jompi yang harus dijaga kelestarianya. Oleh karena itu tidak dibenarkan bila ada aktivitas warga yang mengancam kelestarian hutan dan hal ini tentu merupakan pelanggaran peraturan kehutanan yang sistematis dan perlu ditindaki secara tegas. Masyarakat yang mendiami Kawasan hutan lindung Jompi menolak anggapan Pemerintah Kabupaten Muna bahwa lahan yang mereka tempati adalah hutan negara. Apa yang menjadi penolakan masyarakat didasarkan atas beberapa alasan. Pertama, adanya kisah asal-usul komunitas Watopute yang menempati Kontu secara turun temurun sebagai warisan tanah adat dari Raja Muna, sebelum Kawasan itu ditanami oleh Belanda sekitar 1930-an. Kedua, didalam Kawasan Kontu tersebar beberapa perkuburan tua yang diyakini makam leluhur mereka asal Watopute. Ketiga, penetapan Kontu sebagai kawasan hutan lindung merupakan hal yang semena-mena tanpa ada sosialisasi kepada masyarakat seperti yang diutarakan La Kolo warga 
yang pernah ditangkap dan dipenjara karena dituduh merambah hutan lindung. Sejak kawasan Kontu dihuni secara besar-besaran pasca reformasi 1998, kasus ini telah melewati rentetan yang cukup panjang, kompleks dan hingga kini belum terselesaikan. Penggusuran, pembakaran lahan perkebunan hingga konfrontasi fisik pada 2003 dan 2005 terhadap yang dilakukan Pemerintah tetap membuat masyarakat bertahan hingga sekarang.

\subsection{Respon Terhadap Konflik}

Respon ini dipengaruhi oleh kapital sosial yang ada dalam masyarakat. Apabila kapital social masyarakat lemah maka masyarakat merespons konflik dengan lemah juga, yaitu ditandai oleh tidak adanya tindakan yang menggambarkan perlawanan terhadap pihak lain yang berkonflik (Dinas Kehutanan Kabupaten Muna), misalnya dengan melakukan migrasi untuk bekerja di luar kota. Sedangkan apabila masyarakat memiliki kapital social yang kuat maka masyarakat akan merespons konflik dengan kuat juga yang ditandai dengan adanya perilaku yang menggambarkan suatu perlawanan terhadap pihak lain yang berkonflik (Dinas Kehutanan Kabupaten Muna), melakukan penebangan kayu secara illegal atau melakukan demonstrasi.

Pada kasus yang terjadi di Kawasan hutan lindung Jompi, pada periode sebelum reformasi masyarakat memberikan respons terhadap konflik dengan cara yang berbeda. Sebagian masyarakat memberikan respon yang kuat yaitu yang dieskpresikan dalam bentuk perlawanan sebagai resistensi mereka terhadap konflik yang terjadi dan terdapat pula yang memberikan respons yang lemah, yaitu yang dieskpresikan dengan melakukan migrasi meskipun jumlahnya tidak begitu banyak. Orang yang melakukan migrasi ini adalah yang memiliki kesempatan bekerja di kota, mereka biasanya diajak oleh sanak keluarga yang telah lebih dulu bekerja di kota. Sedangkan pada periode setelah reformasi masyarakat memberikan respons yang sama yaitu merespons dengan kuat dan mengekspresikan dengan cara menebang pohon di Kawasan hutan lindung Jompi dan melakukan demonstrasi hingga berakhir dengan kontak fisik.

Perlawanan ini dilakukan masyarakat untuk mendapatkan akses kedalam Kawasan hutan lindung dan untuk dapat melangsungkan hidup. Masyarakat mengorganisasikan diri dalam perlawanan ini. Seperti yang telah disebutkan sebelumnya, perlawanan masyarakat juga dilakukan dalam bentuk penanaman tanaman pertanian dalam jumlah yang besar seperti pisang, ubi kayu, ubi jalar, talas, kangkung, dan tanaman sayur lainnya. Masyarakat datang ke hutan ketika petugas kehutanan tidak berpatroli, seperti waktu subuh atau sore hari. Hal ini seperti yang diutarakan Pak Martens sebagai berikut:

“... Biasanya setelah sholat subuh bapak ke hutan, petugas kehutanan kan belum berpatroli di waktu seperti itu..."

Masyarakat tetap melakukan aktivitas penanaman meski aturannya jelas telah dikeluarkan oleh pemerintah karena mereka tetap menganggap Kawasan yang mereka tempati adalah warisan leluhur 
mereka, disatu sisi juga masyarakat mempunyai kebutuhan yang mendesak yang harus dipenuhi sehingga mereka tetap melakukan aktivitas didalam Kawasan hutan lindung Jompi dan mengambil sumberdaya yang terdapat dihutan. Seperti penuturan dari Pak La Ode Ndailesa sebagai berikut:

\section{“...Bapak terpaksa bukanya tidak tahu aturan tapi ini demi kelangsungan hidup keluarga Bapak...”}

Selain itu, ada juga yang memilih untuk meninggalkan desa dan bermigrasi ke Kota Kendari untuk bekerja di sana. Tetapi dengan terjadinya krisis moneter dan reformasi, keadaan semakin memburuk.

\subsection{Pohon Konflik}

Pohon konflik dilakukan untuk membantu dalam menyepakati masalah inti, merangsang berbagai sebab dan efek dalam suatu konflik, membantu dalam mengambil keputusan tentang prioritas untuk mengatai berbagai isu konflik dan untuk menghubungkan berbagai sebab dan efek satu sama lain serta untuk memfokuskan actor lainya. Pohon konflik merupakan alat bantu untuk mengurutkan isu-isu konflik (Fisher, et al. 2001). Penggunaan pohon konflik dilakukan dengan menggambar pohon yang terdiri dari batang pohon sebagai masalah inti (isu pokok konflik), akar sebagai penyebab masalah dan ranting sebagai efek atau dampak dari masalah yang ditimbulkan. Melalui pohon konflik, akan diketahui permasalahan inti atau isu pokok konflik yang terjadi dalam pengelolaan kawasan hutan lindung Jompi.

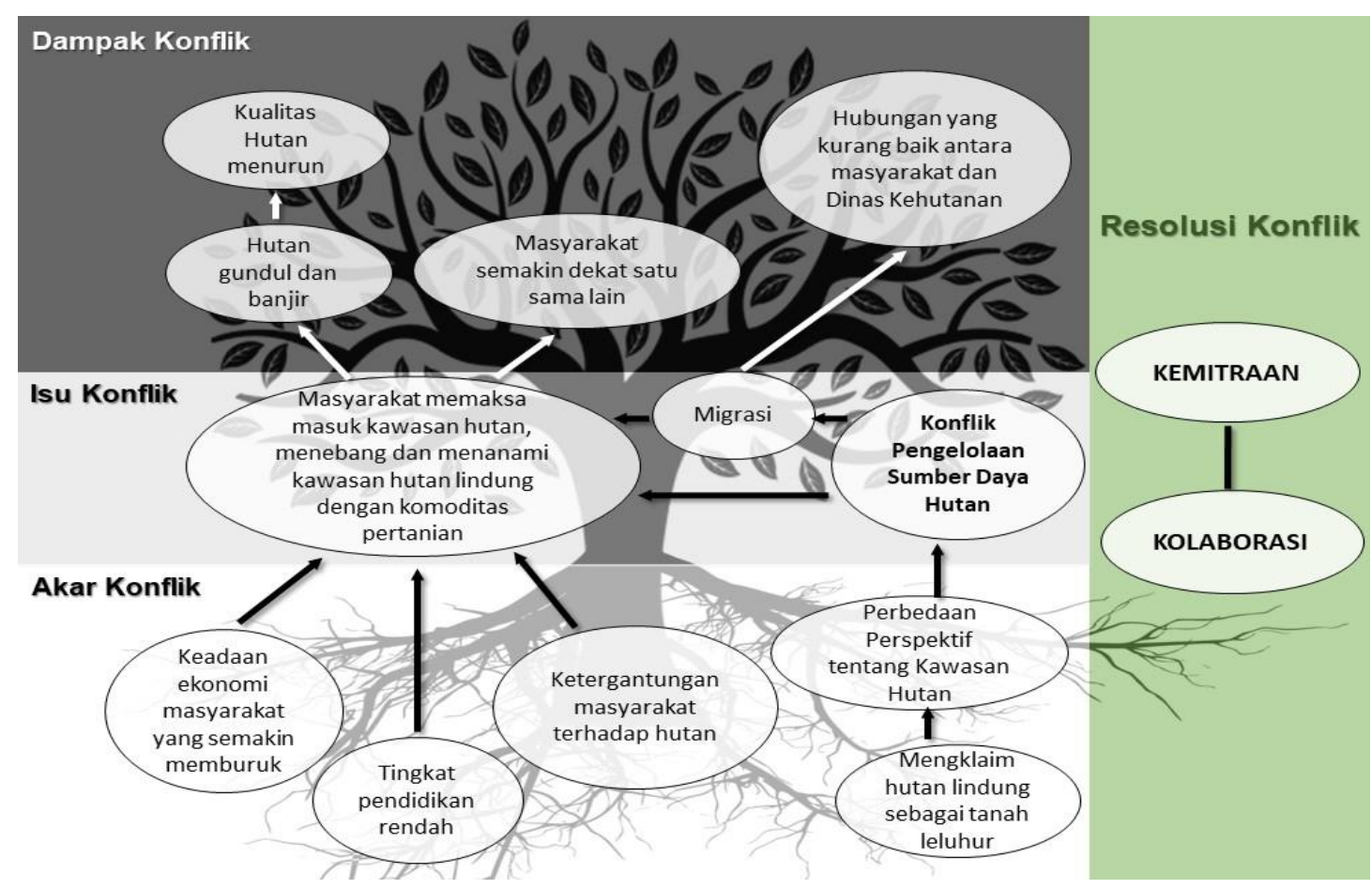

Gambar 1. Pohon Konflik Pengelolaan Sumber Daya Hutan 


\section{KESIMPULAN}

Adapun kesimpulan yang diperoleh dari hasil wawancara terhadap masyarakat yakni masyarakat memberikan respons terhadap konflik dengan cara yang berbeda. Sebagian masyarakat memberikan respon yang kuat yaitu yang dieskpresikan dalam bentuk perlawanan sebagai resistensi mereka terhadap konflik yang terjadi dan terdapat pula yang memberikan respons yang lemah, yaitu yang dieskpresikan dengan melakukan migrasi meskipun jumlahnya tidak begitu banyak.

\section{DAFTAR PUSTAKA}

Dassir, M. 2012. Dinamika Sistem Tenure dan Formasi Sosial Petani Membangun dan Melestarikan Hutan. Makassar. P3I Cipta Media.

Fisher, S.; D. I. Abdi; J. Ludin; R. Smith; S. Williams \& S. Williams. 2001. Mengelola Konflik: Keterampilan dan Strategi untuk Bertindak. S.N. Kartika Sari; M.D. Tapilatu; R. Maharani \& D.N. Rini. Jakarta. The British Council.

Hafrida, Haryadi, Taufik Yahya, Retno Kusniati, Isran Idris. 2914. Penyuluhan Hukum Resolusi Konflik Sumber Daya Alam Di Kabupaten Batanghari. Jurnal Pengabdian pada Masyarakat Vol. 29, No 4.

Handoyo, Suka AP, Ginoga KL. 2011. Identifkiasi Tenurial sebagai Pra-Kondisi Untuk Implementasi REDD+. Jurnal Penelitian Sosial Ekonomi Kehutanan. 8 (4):306-320.

Hendricks, W. 1996. Bagaimana Mengelola Konflik. A. Santoso (Penterjemah). Bumi Aksara. Jakarta. Terjemahan

Iskandar, J., 1992. Ekologi Perdagangan di Indonesia, Studi Kasus Dari Daerah Badui Selatan, Jawa Barat. Pernit Jamban, Jakarta.

Larson, Anne M 2013. Hak Tenurial dan Akses ke Hutan Manual Pelatihan untuk Penelitian. CIFOR. Bogor

Wulan, Yuliana Cahya. et al. 2004. Konflik Kehutanan di Indonesia Sebelum dan Sesudah Reformasi. Centre of International Forestry Research. Bogor. 